\title{
Local Wisdom: Local Paddy Breeding Through Farming Revenue Analysis Approach (Case Study: Indramayu Regency, West Java)
}

\author{
Lilis Imamah Ichdayati ${ }^{a^{*}}$ and Rizki Adi Puspita Sari ${ }^{b}$ \\ ${ }^{\mathrm{a}, \mathrm{b}}$ Department of Agribusiness \\ Syarif Hidayatullah State Islamic University \\ *Email: lilis.imamah@uinjkt.ac.id
}

\begin{abstract}
Farmer's aptitude on paddy breeding developed through Participatory Plant Breeding School (Sekolah Lapang Pemuliaan Tanaman Partisipatoris/SLPTP) was shown by reemerging of local paddy varieties. From 2002 up to 2010, Indramayu breeder farmers have succesfully created 400 varieties of paddy seeds which some of them having local superiority. This succesfulness had attracted other surrounding farmers to cultive those local paddy varieties in larger areas which eventually generated economic impact to the breeder farmer and others. Creativity of breeder farmer protected by Decision of MKRI No 99/PUU-X/2012, therefore their seeds and unhulled rice (gabah) are able to be sell off to their community. This research aimed (1) to analyze the revenue of paddy farming of breeder farmer and market share of paddy grain/unhulled rice (gabah) and local rice in Indramayu District; (2) to cognize local wisdom content on the implementation of environmental friendly and sustainable rice paddy farming. Research conducted in Indramayu District. Breeder farmers in 13 districts of local paddy centers taken as samples through purposive sampling technique. Primary data obtained from interview guided by questionnaire from July to August 2016. Tools of analysis used were revenue analysis and descriptive analysis related to local wisdom in rice paddy farming. Results of the research are as follows : (1) Breeder farmers gained major profit both from retrenchment of input cost (local seeds, organic fertilizers, organic pesticides) and enhancement of paddy productivity on the average of 66 quintal/hectares. Traders gave credence on paddy qualities by purchasing it on higher price with the result that higher profit acquired. Obstacles faced are annually climb up of rent expense on paddy fields and labor cost (farm workers) which increasingly rare and hereinafter contributed as highest portion of farming cost, reaching approximately 52 to $67 \%$ of it. (2) Local wisdom emerging in social institutions of paddy farming such as dissemination of breeding output by way of inter-farmer seeds exchange, 'bawon' wage payment system for 'ceblokan', 'nderep sawah' and 'arisan padi' (regular social gathering) activities are figuration of 'gotong royong' (mutual cooperation) organizing customs of Indramayu. For breeder farmers, awareness have arised on the meaning of paddy farming aside from economical, ecological and social sense : it constitute life itself.
\end{abstract}

Keywords: Paddy seeds, Revenue, Total cost, Local wisdom

\section{Introduction}

Indramayu Regency, well-known as grannary in West Java has succesfully increased paddy production for about 1,68 million tons in 2013 , contributed $14 \%$ of West Java production (12,08 million tons) equal to $2,4 \%$ of national paddy production [1]. The high production caused by accrued wetlands and planting area which in 2013, constitued 116,8 thousand hectares irrigated rice fields, approximately $55 \%$ of 204 thousand hectares Indramayu District area. It lead Indramayu on the first position of rice producer in West Java followed by Karawang and Subang in the second. Similarly on productivity, Indramayu stick up on top which in 2013 attained about 6,2 tons per hectare [2].

Differs from other sectors, the agricultural growth is driven more by community investment which might not recorded in state institutions. To date, community investment estimated approximately $68 \%$, while government contribution is only around $24 \%$ and private sector is about $8 \%$ [3]. Accordingly, effective role of the (local) government, basically lies on the effort to actuate community investment in the agricultural sector by creating conducive business climate.

Since Participatory Breeding School (SLPTP) program was held in 2002 up to 2010, Indramayu breeder farmers have succesfully created approximately 400 variant of paddy varieties. Several of the generated varieties hold superiority of ideal paddy seeds such as weather resistant and high productivity traits. The succesfulness have appealed other surrounding farmers to cultivate the 'ideal seeds' in the larger areas. The activities impacted economically to breeder farmers as well as others. There are striking differences on the paddy farming using 'ideal seeds'. Farmers' role are dominant on cultivating seeds, applicating organic fertilizers and organic pesticides which made by themselves.

\section{The Purpose of The Study}

Based on the formulation above, the purpose of this study were to analyze the business revenue of breeder farmers and market share of unhulled rice (gabah) and local 
rice in Indramayu District and to cognize local wisdom content formed through paddy farming cultivation in paddy field conducted by breeder farmers.

\section{The Scope of The Study}

The succesfulness of breeder farmers getting permission to disseminate their creation of paddy varieties in limited community will be impacted economically. Accordingly, it is necessary to conduct the study on wether breeder farmers could improve their prosperity through paddy farming business using their own creation of paddy varieties; how these varieties widely spreading into other surrounding farmers outside the village and forming trade channels. This study also attempted to trace on how far the superiority of the creation seeds were capable to contribute on the prosperity of the creator. The study framework used simple analysis of business revenue and traced local wisdom maintained through farming activities which is environment friendly and adaptable to environmental challenges.

\section{Method}

Research locationed in centres of local paddy seeds and local paddy production, Indramayu Regency, West Java. Data collection conducted for 4 month (from May to August 2016). Samples were taken using non probability sampling technique i.e 'purposive sampling' that is farmers of Indramayu District conducted breeding in 13 districts and 31 villages. Number of samples used in the study were 30 people. Data source used in the study is primary data, obtained from result of questionnaire-guided interview. Data types used comprising sample characteristic, production, factors of production and financial condition of farmers.

\section{Result and Discussion}

\section{a. Potential Production of Indramayu Paddy}

Economic growth of Indramayu Regency in 2013 supported by agricultural sector was in the second position reaching $19,62 \%$ far less than mining sector particularly on petroleum and gas which contributed approximately $31,95 \%$ [4]. Contribution of agricultural sector in PDRB Indramayu District is tends to decrease from year to year. Changes in PDRB represents shifting of economic structure from economy based on agricultural activities which perceived as traditional economic activity towards economy based on industry which perceived as modern economy. This situation is not happened only in Indramayu District but also tends to spread evenly in other districts which relied on agricultural sector as its labor storage. However, from structure of PDRB per district in Indramayu Regency, it showed that agricultural sector still occupy first position followed by trade and services sectors, thus it still become the mainstay of economic growth for Indramayu Regency.

\section{b. Business Farming Cost}

Total cost of rice farming were consist of land rent cost, input costs, labor costs and equipment costs. Descriptively, it is distinguished between farmers cultivating superior seeds of government (mostly Ciherang) and the farmers cultivating 'Idaman' seed of breeder's creation.

Table 1. Average Total Cost of Farmers Cultivating Seeds of Government and 'Idaman' Seeds Per hectare, Land rents Status, August 2016 (Rp/ha)

\begin{tabular}{|l|l|l|l|l|l|}
\hline No & Cost Component & $<2$ hectare & $1-2$ hectare & $0,5-1$ hectare & $<0,5$ hectare \\
\hline & Goverment Seeds & & & & \\
\hline 1 & Land Rent Costs & & $8,106,000$ & & $14,000,000$ \\
\hline 2 & Input Costs & & $2,312,025$ & & $1,680,000$ \\
\hline 3 & Labor Costs & & $1,600,750$ & & $7,420,000$ \\
\hline 4 & Equipment Costs & & $10,039,567$ & & $3,360,000$ \\
\hline & Total costs & & $18,145,567$ & & $12,460,000$ \\
\hline & Total plus rent costs & & & & $26,460,000$ \\
\hline & Idaman Seeds & $6,622,000$ & & $9,807,000$ & $9,030,000$ \\
\hline 1 & Land Rent Costs & $1,142,000$ & & $2,265,550$ & $2,488,000$ \\
\hline 2 & Input Costs & $5,520,000$ & & $7,472,500$ & $5,278,000$ \\
\hline 3 & Labor Costs & $1,540,000$ & & $2,716,000$ & $2,240,000$ \\
\hline 4 & Equipment Costs & $8,202,000$ & & $12,454,050$ & $10,006,000$ \\
\hline & Total costs & $14,824,000$ & & $19,809,300$ & $19,428,000$ \\
\hline & Total plus rent costs & & & \\
\hline
\end{tabular}


The use of Idaman seeds contributed to the expenditure of farmers as it can be seen in table 1 that total cost of farmers cultivating Idaman seeds were lower than total cost of farmers cultivating Government seeds. It is possible due to retrenchment of purchasing seeds, organic fertilizers and organic pesticides which supported by routine observations of paddy growth.

\section{c. Productivity}

Idaman seeds cultivated by 15 farmers respondent were consist of 9 varieties of breeder's creation spreading in 7 districts. While government superior seeds cultivated by 17 farmers were only consist of 3 varieties which spreading in 13 districts. Productivity is a ratio of input and output; which in this case is paddy production per hectares area of paddy fields (table 2 ).

Table 2. Productivity of Each Paddy Varieties of Idaman Seeds and Government Seeds

\begin{tabular}{|c|c|c|c|c|c|}
\hline No & Varieties & $\begin{array}{l}\text { Number of } \\
\text { farmers }\end{array}$ & $\begin{array}{l}\text { Large of paddy } \\
\text { fields (ha) }\end{array}$ & $\begin{array}{l}\text { Production } \\
\text { (Kw) }\end{array}$ & $\begin{array}{l}\text { Productivity } \\
\text { (Kw/Ha) }\end{array}$ \\
\hline & Idaman seeds & \multicolumn{3}{|l|}{15 people } & \\
\hline 1 & Sri Putih, anonim & 1 & 2.5 & 150 & 60.00 \\
\hline 2 & Bongong & 2 & 4.0 & 280 & 70.00 \\
\hline 3 & Pandan wangi & 2 & 2.2 & 154 & 70.00 \\
\hline 4 & Gading putih & 1 & 0.71 & 30 & 42.25 \\
\hline 5 & F8 Riau-mayangsari & 1 & 0.71 & 30 & 42.25 \\
\hline 6 & Bravo & 3 & 2.14 & 196 & 91.47 \\
\hline 7 & $\begin{array}{llll}\begin{array}{l}\text { Bongi } \\
\text { wangi) }\end{array} & & & \\
\end{array}$ & 1 & 0.57 & 28 & 49.00 \\
\hline 8 & $\begin{array}{l}\text { Anonim (ciherang vs Asa } \\
\text { kebo) }\end{array}$ & 2 & 0.93 & 39 & 41.87 \\
\hline \multirow[t]{2}{*}{9} & Borang & 2 & 0.43 & 30 & 63.00 \\
\hline & Government seeds & \multicolumn{4}{|l|}{17 people } \\
\hline 10 & IR padi 10 & 1 & 3.57 & 250 & 70.00 \\
\hline 11 & IR Ciherang & 11 & 11.5 & 740.3 & 64.37 \\
\hline 12 & IR Kebo & 5 & 6.71 & 354 & 52.76 \\
\hline
\end{tabular}

The breeder's creation seeds resulted highest productivity is Bravo varieties from Wanguk Village, Anjatan District which were capable to produce 91,47 quintal per hectare of paddy; far beyond Ciherang productivity of 64,37 quintal/hectare. It showed that Bravo varieties were considerably suitable to be cultivated in paddy fields of Wanguk Village technically-irrigated in the Gadu season. Fertilizer applicated were mixture of organic fertilizers supported by chemical fertilizers; while pesticides used were organic pesticides. Other varieties produced high yields were Borang, Bongong, Sri Putih and Pandan Wangi.

\section{Conclusion and Recommendation}

Based on the analysis result and discussion, we can conclude that :

1. Revenue analysis of paddy farming business operated by breeder farmers resulted :

a. The narrower paddy field rented, the higher the rent cost per year, the higher total cost of farming with the largest component of total cost were contributed by labor costs reaching $52-67 \%$, thus harvest sale were not able to cover the total cost and the farmers suffered losses. The area of paddy cultivation in rent status which capable to give profit were above 1 hectare.

b. The use of breeder's creation seeds (Idaman seeds) provide savings in expenditure for seed, fertilizer and pesticides so as to increase farmers' profit. The quality of paddy harvested were trusted by traders and grinders resulted high selling price of the grain and eventually providing benefit for breeder farmers.

c. The average productivity of Idaman seeds of 66 quintal per hectare is higher than national superior seed productivity of 61,7 quintal per hectare

d. Breeder farmers hold bargaining power and are able to cut down market chain by directselling of ready-to-cook rice to middle-upper class consumers. The selling price of organic rice is between Rp. 12.000 until Rp. 20.000 per kilograms depend on the rice type. 
2. Local knowlege formed through practice of rice cultivation in paddy fields implemented by breeder farmers are as follows : a) preserve the institutions of paddy farming such as catu/bawon wage system, "ngopyori pari", "gèdèngan", "mbibiti", "mengetim", "ngipuk", b)Conducting inter-farmers seed exchange as a form of preserving 'seed gene' and conserving natural resources biodiversity of paddy plant; c) Enhancing awareness on the meaning of paddy farming aside from economical, ecological and social sense : it constitute life itself.

\section{References}

[1] BPS. 2015. Indramayu dalam Angka 2014. BPS Kabupaten Indramayu.

[2] BPS. 2014. Indramayu dalam Angka 2013. BPS Kabupaten Indramayu.

[3] Casdira. 2009. Paradoks Lumbung Padi Jawa Barat. Mengais Makna. Retrieved from https://casdiraku.wordpress.com/2009/03/15/potretpertanian-indramayu-paradoks-lumbung-padi-jawa-barat/ (Accessed 9 February 2016).

[4] PDRB. 2013. PDRB Perkecamatan Kabupaten Indramayu Menurut Lapangan Usaha Tahun 2013. Kab. Indramayu. 